\title{
Temporal attachment dynamics by distinct bacterial taxa during a dinoflagellate bloom
}

\author{
Xavier Mayali ${ }^{1, *}$, Peter J. S. Franks ${ }^{2}$, Ronald S. Burton ${ }^{2}$ \\ ${ }^{1}$ Lawrence Livermore National Laboratory, 7000 East Avenue, Livermore, California 94550, USA \\ ${ }^{2}$ Scripps Institution of Oceanography, University of California San Diego, 9500 Gilman Drive, La Jolla, \\ California 92093-0202, USA
}

\begin{abstract}
Limited quantitative information exists on the physical interaction between specific taxa of heterotrophic bacteria and phytoplankton in pelagic aquatic environments. Using catalyzed reporter deposition fluorescence in situ hybridization (CARD-FISH), we quantified bacterial attachment to the cells of the dinoflagellate Lingulodinium polyedrum in 39 surface samples collected during a natural bloom in summer 2005 off the coast of La Jolla, California, USA. Using a ribosomal RNA based tunable array with Luminex ${ }^{\circledR}$ bead technology, we also quantified the relative abundances of 11 particle-associated bacterial taxa during this time, including 8 members of the Bacteroidetes division. Bacterial colonization of dinoflagellate cells was generally low (mean $<2$ bacteria $\operatorname{alga}^{-1}$ ) but increased during the days preceding bloom decline events. This indicates that physical associations, and thus potentially physiological interactions among bacteria and dinoflagellates, changed over the course of the algal bloom cycle. The 11 detected bacterial taxa exhibited diverse patterns of colonization over time, suggesting that they mediated different types of interactions with the dinoflagellates. Some bacterial types were only detected during the early bloom phase, others peaked in abundance during peaks in algal numbers, and still others peaked following bloom decline events. Our data linking the temporal succession of different bacterial colonizers to algal bloom dynamics exemplify the idea that microscale, species-specific interactions between bacteria and protists can result in large-scale ecosystem level changes that can impact phytoplankton community structure in the coastal ocean.
\end{abstract}

KEY WORDS: Algal-bacterial interactions • Bloom dynamics • Parasitism • Phycosphere . Roseobacter $\cdot$ Bacteroidetes $\cdot$ Dinoflagellate

\section{INTRODUCTION}

A major portion (30 to $50 \%$ ) of phytoplankton primary production is incorporated by bacteria (Cole et al. 1988), in part through algal dissolved organic matter excretion followed by bacterial hydrolysis and uptake. Another strategy utilized by bacteria is attachment to organic particles (Paerl 1975) subsequently shown to be a major site of bacterial activity (Smith et al. 1992). Particles can be live or dead or a combination thereof, and while bacteria readily colonize algal detritus (Caron et al. 1982), some studies have suggested that live phytoplankton cells are relatively free from bacterial colonization (Droop \& Elson 1966, Kogure et al. 1981). Surprisingly, no studies have directly quantified bacterial colonization on algal cells in the ocean. In a previous study, attachment of bacteria to particles (operationally defined by retention on filters of specified pore size) was negatively correlated to chlorophyll and primary productivity (Albright et al. 1986), suggesting that growing (healthy) algal cells harbor fewer attached bacteria than senescent ones. Another study, examining a microcosm algal bloom, further suggested that bacterial attachment to algal cells is a function of encounter probability (Vaqué et al. 1989): bacterial attachment increased when both free-living bacteria and algal cell numbers were high. These previous studies suggested that a dynamic physical interaction exists between phytoplankton and bacteria, but a quantitative analysis of bacterial attachment to phyto- 
plankton in nature is clearly warranted to further support this idea.

The concept of the phycosphere, the surface of microalgae and the surrounding boundary layer, was first introduced by Bell \& Mitchell (1972) as an environment physically and chemically distinct from the surrounding water that could favor the growth of certain microbial taxa. Recent studies have indeed documented distinct microbial communities attached to dinoflagellates (e.g. Hasegawa et al. 2007), but information about the ecological role of these phycosphereassociated bacteria is lacking. Using bacterial isolates that are usually phylogenetically different from those commonly found in the ocean, many studies have documented both positive and negative interactions between bacteria and phytoplankton in laboratory coculture experiments (reviewed by Kodama et al. 2006). Documenting such interactions in nature is more complex. One strategy may be to examine the temporal patterns of bacterial colonization of the algal cells in the context of a well-defined bloom cycle, as has been done with viral (Bratbak et al. 1993) and eukaryotic pathogen (Coats et al. 1996) infection. Unlike viruses and obligate pathogens, however, bacteria have a greater variety of effects (e.g. commensal, mutualist, parasitic), and these may change based on environmental factors or physiological status of the algal host (Azam \& Smith 1991). Nevertheless, temporal patterns of bacterial attachment during bloom cycles may help to constrain hypotheses about bacterial effects on bloom progression.

Here, we employed catalyzed reporter deposition fluorescence in situ hybridization (CARD-FISH; Pernthaler et al. 2002) with a Bacteria-specific probe and epifluorescence microscopy to quantify bacteria attached to cells of the dinoflagellate Lingulodinium polyedrum in samples collected during a natural bloom of this organism. To link bacterial colonization dynamics to bacterial identity, we also employed a molecular fingerprinting technique detecting 16S rRNA ribotypes previously found at this location (Mayali et al. 2010). The first objective of the present study was to document the extent of bacterial attachment to dinoflagellate cells. Several factors have made this goal problematic in the past, including chlorophyll autofluorescence and the difficulty in discriminating plastid or mitochondrial signal from bacteria with DNA-specific dyes such as DAPI. The technique employed here circumvents this problem. The second objective was to examine the dynamics of bacterial attachment during the L. polyedrum bloom to test the hypothesis that bacteria play mutualistic, saprophytic, or parasitic roles in algal bloom dynamics. In particular, we were interested in following the colonization dynamics of different bacterial taxa over time. We hypothesized that if different bacteria mediated different physiological interactions with their algal host, they would reveal different colonization dynamics over time. For example, bacteria that specialize in breaking down organic matter on dead algal cells (saprophytes) would show increased colonization after bloom events, when detritus concentration is high in the water. Conversely, bacteria that are beneficial to the algal cells (mutualists) would be found during periods of high algal abundance. Further, bacteria that are competitive or parasitic with their algal host would show increased abundance preceding bloom declines, similar to what has been found with eukaryotic parasites (Coats et al. 1996) and algal viruses (Bratbak et al. 1993).

\section{MATERIALS AND METHODS}

Field sampling. Surface seawater samples were collected from the Scripps pier $\left(32^{\circ} 52.015^{\prime} \mathrm{N}, 117^{\circ}\right.$ $15.428^{\prime} \mathrm{E}$ ) between 11:00 and 15:00 $\mathrm{h}$ and fixed in 5\% unbuffered formalin (= $1.8 \%$ formaldehyde). Samples were then handled as below or frozen at $-20^{\circ} \mathrm{C}$ (Lam \& Cowen 2004). The bloom was interrupted by a $10 \mathrm{~d}$ period and a subsequent $5 \mathrm{~d}$ period when algal numbers were low and ocean discoloration was not evident. We did not sample these periods, as we had assumed the bloom was terminated. As the bloom reappeared, sampling resumed as before. For all field samples, algal cell numbers in fixed samples were enumerated in 24-well plates with an inverted microscope (Olympus IX-71) under brightfield illumination. Bacterial attachment was quantified after CARD-FISH (see below). Between 10 and 70 Lingulodinium polyedrum cells were examined for each sample (low sample sizes corresponded to days when L. polyedrum abundances were low) for a total of 1636 algal cells. Free-living bacteria were enumerated by flow cytometry with a FACSort flow cytometer (BD Bioscience). Samples were fixed in $5 \%$ formalin for $30 \mathrm{~min}$ and frozen at $-80^{\circ} \mathrm{C}$ until analysis. Samples were thawed on ice, stained for $15 \mathrm{~min}$ in the dark in $1 \times$ SYBRgreen II (Invitrogen) and diluted 10- or 100-fold. Quantification of cells was based on green fluorescence and forward scatter (Lebaron et al. 1998). Unstained samples and stained axenic L. polyedrum cultures served as controls.

CARD-FISH. To quantify the number of bacteria attached to the surface of dinoflagellate cells, CARDFISH was used with a protocol slightly modified from Pernthaler et al. (2002). Fixed field samples were thawed (if previously frozen), gravity-settled overnight (or gently centrifuged at $200 \times g, 5 \mathrm{~min}$ ), washed in $1 \times$ phosphate-buffered saline (PBS), re-suspended in $50 \%$ ethanol, and stored at $-20^{\circ} \mathrm{C}$. This protocol pre- 
vented free-living bacterial cells from becoming artificially attached to algal cells during filtration (data not shown). Samples were spotted on Teflon-coated 10well slides and air dried. Wells were then spotted with $5 \mu \mathrm{l} 0.1 \%$ low melting point agarose, dried, and the entire slide was dipped again in $0.1 \%$ low melting point agarose and air dried. Wells were incubated in $1 \mathrm{mg} \mathrm{ml}^{-1}$ lysozyme (Sigma) in Tris-EDTA (TE) buffer at $37^{\circ} \mathrm{C}$ for $1 \mathrm{~h}$, washed 3 times in MilliQ water, incubated for $10 \mathrm{~min}$ in $0.1 \mathrm{~N} \mathrm{HCl}$, washed 3 times in $1 \times$ PBS (3 min), and dehydrated in an ethanol series (50\%, $80 \%, 95 \%$ for $3 \mathrm{~min}$ each). Slides were incubated for $2 \mathrm{~h}$ at $35^{\circ} \mathrm{C}$ in a hydrated chamber with hybridization

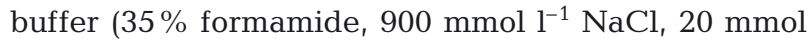
$\mathrm{l}^{-1}$ Tris, $0.01 \%$ sodium dodecyl sulfate [SDS], $20 \%$ Roche Diagnostic Boehringer blocking reagent) containing $1 \mu \mathrm{l}$ of probe for every $25 \mu \mathrm{l}$ of buffer (final probe concentration $=2 \mathrm{ng} \mathrm{ll}^{-1}$ ). We used the Bacteriaspecific probe EUB338 5'-GCT GCC TCC CGT AGG AGT-3' (Amann et al. 1995) conjugated with horseradish peroxidase (Eurogentec). Slides were subsequently washed for $20 \mathrm{~min}$ at $37^{\circ} \mathrm{C}$ in wash buffer (70 mmol $\mathrm{l}^{-1} \mathrm{NaCl}, 5 \mathrm{mmol} \mathrm{l}^{-1}$ EDTA, $20 \mathrm{mmol} \mathrm{l}^{-1}$ Tris, $0.01 \%$ SDS), rinsed in Milli-Q, and overlaid with TNT buffer $\left(0.1 \mathrm{~mol} \mathrm{l}^{-1}\right.$ Tris- $\mathrm{HCl} \mathrm{pH} \mathrm{7.6,0.15} \mathrm{mol} \mathrm{l}^{-1} \mathrm{NaCl}$, $0.05 \%$ Tween-20) for $15 \mathrm{~min}$. Wells were then incubated with $1 \mu \mathrm{l}$ tyramide-Alexafluor488 (Invitrogen) in $100 \mu \mathrm{l} 1 \times$ PBS with $0.01 \%$ Boehringer blocking reagent for $30 \mathrm{~min}$, washed with TNT buffer at $55^{\circ} \mathrm{C}(10 \mathrm{~min})$, rinsed in water, air dried, stained with DAPI (Porter \& Feig 1980), and mounted with Vectashield (Vectorlabs). Negative controls were always run simultaneously and included either no-probe or Archaeaspecific probe ARC915 5'-GTG CTC CCC CGC CAA TTC CT-3' (Amann et al. 1990), which gave similar signals since the permeabilization protocol was not designed for archaea. bacteria attached to dinoflagellate cells were visualized on an Olympus BX51 epifluorescence microscope with a standard DAPI filter set and a FITC-Texas red dual band filter set (Chroma Technology). Up to 20 individual bacteria on an algal cell could be counted with minimal error, while higher numbers, which were very rare, were categorized as 20 for statistical analyses. Our counts were most probably underestimates due to the inability to detect all probe-positive bacterial cells located behind or inside the autofluorescent algal cells. For temporal crosscorrelation analyses, data were log transformed to satisfy assumptions of normality. Bacterial data were lagged in relation to algal data: a lag in the negative direction (e.g. -2 d) meant that the bacterial data were moved 2 d back. Correlation analyses for each lag were performed in JMP v5.0.

Attached bacterial community dynamics. Fixed gravity-settled algal cells (and other settled particles) from the collected field samples were analyzed following PCR with a recently described hybridization assay utilizing the Luminex 100 flow cytometer (Mayali et al. 2010). The assay was designed to target 24 bacterial taxa that included abundant coastal heterotrophic bacteria as well as less abundant taxa associated with algal blooms. One $\mu$ l samples were added to $5 \mu$ LyseN-Go reagent (Pierce Scientific) and incubated according to the manufacturer's instructions to lyse the cells. PCR with Bacteria-specific biotinylated primers was then performed on the lysate with 35 amplification cycles. The number of cycles was increased from 30 in the original protocol due to the low quantity of starting material analyzed here. PCR products were denatured at $95^{\circ} \mathrm{C}$ for $5 \mathrm{~min}$ and incubated with 1000 beads of each type (24 types, each type with a different oligonucleotide probe) at $52^{\circ} \mathrm{C}$ for $2 \mathrm{~h}$ in $1 \times$ TMAC buffer ( $3 \mathrm{M}$ tetramethylammonium chloride, $0.1 \%$ SDS, $50 \mathrm{mM}$ Tris-HCl [pH 8.0], and 4 mM EDTA [pH 8.0]). Incubations were performed in skirted PCR plates covered with plastic film in a thermal cycler. After incubation, samples were washed with fresh TMAC buffer and spun down at $2000 \times g$ for $3 \mathrm{~min}$. After removing the supernatant, the beads were incubated for $10 \mathrm{~min}$ with streptavidin-phycoerythrin (Invitrogen; $250 \times$ dilution) in the dark at $52^{\circ} \mathrm{C}$, washed, and resuspended in $50 \mu \mathrm{l}$ TMAC buffer. Data acquisition on the Luminex instrument was performed with Luminex software v 1.7, and a minimum of 100 beads of each type were analyzed. Raw Luminex fluorescence data were blank subtracted (blank = negative $\mathrm{PCR}$ reaction), and data represented the average of duplicate PCR reactions. Due to differential probe/target hybridization kinetics, Luminex fluorescence data from different probes could not be directly compared with one another (Spiro et al. 2000). However, the fluorescence of 1 probe across different samples could be compared to provide relative quantification (Mayali et al. 2010). Cross-correlation analyses were performed among the datasets to determine whether taxa were correlated with one another with temporal lags. This procedure shifts datasets forward and backwards in time and determines the correlation coefficients of the shifted (and the original) datasets. Correlations with coefficients greater than 0.4 were considered potentially meaningful (Ideker et al. 2001) and were subsequently used for network diagrams. In order to group bacterial taxa sharing generally similar temporal dynamics, we also performed a cluster analysis, using Ward's method, on the pairwise correlations (with no time lags). Taxa were considered to belong to a group if their correlation coefficients with other member(s) of the group were $>0.7$. This cutoff was not arbitrary but was based on the empirical finding that using coefficients $<0.7$ led to taxa belonging to more than 1 group. 


\section{RESULTS}

\section{Bacterial abundances and attachment during the bloom}

The Lingulodinium polyedrum bloom sampled in this study was nearly monospecific, based on microscopic examination and good agreement between $L$. polyedrum cell abundances and extracted chlorophyll a (Fig. 1a). The bloom exhibited 3 major peaks in algal abundance, although it was not possible to determine whether the different peaks represented separate events or whether it was the same bloom that returned. Sampling began on 14 June, when the bloom was already present. Algal abundances remained high $\left(>100\right.$ cells ml $^{-1}$ ) and the water discolored until 7 July, when algal abundances decreased rapidly over the course of 2 d (by 8 July, abundances were only 5 cells $\mathrm{ml}^{-1}$ ). Water discoloration briefly returned on 20 July but for only a few days (by 25 July, abundances were

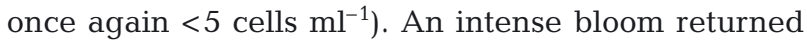
on 2 August, lasting until 9 August and followed by a decline between 9 and 11 August.

Total bacterial abundances at the surface during the bloom period were elevated compared to non-bloom conditions. Average bacterial abundances at Scripps pier, as in most coastal mesotrophic environments, are

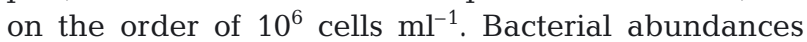
during the Lingulodinium polyedrum bloom ranged from $1 \times 10^{6}$ to $2 \times 10^{7}$ cells ml $^{-1}$ (Fig. 1 b), at times 20 fold higher than average. Cross-correlation analyses between $L$. polyedrum abundances and total bacteria were positive with $0,+2 \mathrm{~d}$, and $-2 \mathrm{~d}$ lags (Table 1), although 1 of these relationships (+2 d lag) was no longer significant after adjustment of the $\mathrm{p}$-value for multiple tests. These positive cross-correlations are indicative that the 2 datasets were connected with one another at different timescales and suggest both a positive response by the bacteria to the presence of $L$. polyedrum and a positive response of L. polyedrum to the presence of bacteria.

The first measure of bacterial colonization examined was colonization frequency, defined as the percentage of algal cells colonized by at least 1 bacterium. This index ranged from 6 to $100 \%$ (Fig. 1c). Colonization frequency was highly variable in magnitude and time, as Lingulodinium polyedrum cells could go from being nearly $100 \%$ colonized to $<10 \%$ (and vice versa) in a few days. Cross-correlation analyses between colonization frequency and algal abundances were not statistically significant after correction for multiple tests. However, examination of such analyses still provides some useful information, particularly if some of these analyses were statistically significant before p-value adjustment. The strongest relationship $(\mathrm{r}=-0.39)$ was a negative relationship between the 2 datasets with a lag of $+2 \mathrm{~d}$ (bacterial colonization peaked $2 \mathrm{~d}$ before algal crashes; Table 1). This implies that (on average) $2 \mathrm{~d}$ before a decline in algal numbers, the percentage of algal cells colonized by bacteria was high. The second measure of bacterial attachment examined was colonization intensity,

Fig. 1. Quantification of various parameters from surface water samples collected during the summer 2005 bloom at Scripps Pier, California, USA. (a) Lingulodinium polyedrum abundances (black line) and extracted chlorophyll a (chl a) from the Scripps Pier Chlorophyll Program (gray line). (b) Total bacterial abundances. (c) Bacterial colonization frequency (defined by the percent of L. polyedrum cells colonized by at least 1 visible bacterium). (d) Bacterial colonization intensity (defined by the average number of bacteria colonizing L. polyedrum cells). Error bars: $95 \%$ confidence intervals 
Table 1. Lingulodinium polyedrum. Cross-correlation analyses of abundances with 3 bacterial indices during the summer 2005 bloom at Scripps pier. Lags indicate the number of days the bacterial data were moved in relation to the algal data to calculate correlations. p-values before adjustment for multiple tests are shown (ns: not significant at $\alpha=0.05$ )

\begin{tabular}{|c|c|c|c|c|c|c|c|}
\hline $\operatorname{Lag}(\mathrm{d})$ & -3 & -2 & -1 & 0 & 1 & 2 & 3 \\
\hline Bacteria $\left(\mathrm{ml}^{-1}\right)$ & $\mathrm{ns}$ & $\begin{array}{c}r=0.54 \\
p=0.0028\end{array}$ & $\mathrm{~ns}$ & $\begin{array}{c}r=0.75 \\
p<0.0001\end{array}$ & ns & $\begin{aligned} r & =0.40 \\
p & =0.037\end{aligned}$ & $\mathrm{~ns}$ \\
\hline $\begin{array}{l}\text { Colonization } \\
\text { intensity }\end{array}$ & $\begin{array}{l}r=-0.33 \\
p=0.036\end{array}$ & ns & ns & ns & ns & $\begin{array}{l}r=-0.33 \\
p=0.016\end{array}$ & ns \\
\hline $\begin{array}{l}\text { Colonization } \\
\text { frequency }\end{array}$ & ns & ns & ns & ns & ns & $\begin{array}{l}r=-0.39 \\
p=0.031\end{array}$ & ns \\
\hline
\end{tabular}

results indicate that on average, algal numbers reacted negatively to increased bacterial colonization intensities after $2 \mathrm{~d}$, followed by increased bacterial colonization after $3 \mathrm{~d}$.

\section{Attachment dynamics of bacterial taxa}

To examine the phylogenetic identity of bacteria attached to particles during the Lingulodinium polyedrum bloom, we employed a PCR-based hybridiza-

defined as the mean number of bacteria attached to each L. polyedrum cell. Sample means ranged from 0 to 12 bacteria per algal cell (Fig. 1d). Most L. polyedrum cells had a few or no attached bacteria (Fig. 2a,b), although on rare occasions algal cells had $>20$ bacteria (Fig. 2c). On the other hand, bacteria heavily colonized algal detritus (Fig. 2d). Cross-correlation analyses of colonization intensity and algal abundance were not significant after $\mathrm{p}$-value adjustment for multiple tests. Two of these analyses, which were significant before $p$-value adjustment, resulted in negative cross-correlations with $\mathrm{a}+2 \mathrm{~d}$ lag (bacteria peaked $2 \mathrm{~d}$ before an algal crash) and a $-3 \mathrm{~d}$ lag (bacteria peaked $3 \mathrm{~d}$ after an algal crash; Table 1). These
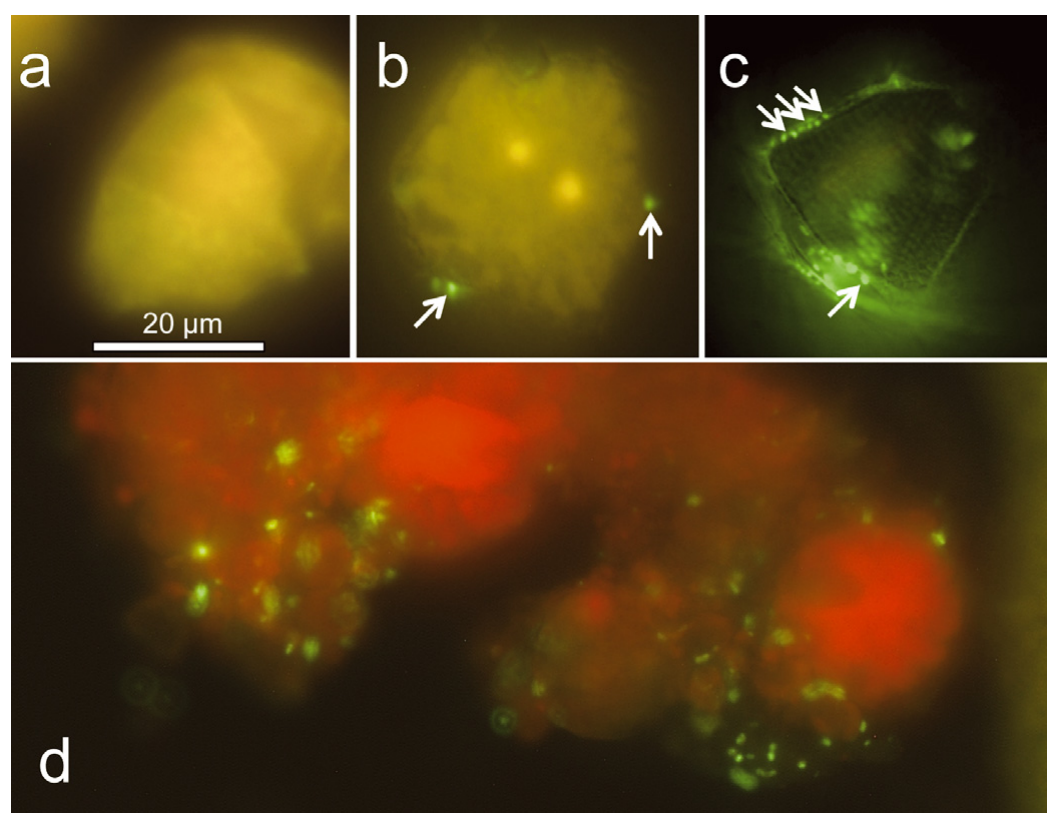

Fig. 2. Lingulodinium polyedrum. Epifluorescence micrographs showing fieldcollected cells after CARD-FISH with probe eub338 specific for Bacteria, some of which are indicated by arrows. Red corresponds to the chlorophyll signal and green to the bacterial probe; (a) uncolonized algal cell, (b) algal cell colonized by 2 bacteria, (c) algal cell colonized by $>20$ bacteria, (d) algal detritus, heavily colonized by bacteria. Scale bar in (a) refers to all panels tion assay designed to target surface microbial communities from this location (Mayali et al. 2010). The assay enables the simultaneous relative quantification of 24 heterotrophic bacterial taxa, some of which were detected in clone libraries constructed from a sample taken during a bloom of a different dinoflagellate species (Ceratium sp.). Eleven of the 24 targeted bacterial taxa were positively detected from the L. polyedrum bloom particle samples, defined as a fluorescence signal greater than twice the background. Detected taxa included 3 members of the Proteobacteria and 8 members of the Bacteroidetes. Nine of these 11 taxa were previously detected in algal blooms (Table 2), including 4 in an L. polyedrum bloom in 1997 sampled at the same location (Fandino et al. 2001). The temporal dynamics of the detected taxa were quite variable but could be quantitatively subdivided into 5 groups based on cluster analysis and shared pairwise correlation coefficients $>0.7$ (Fig. 3). The first ('Group I' in Fig. 3) included 2 taxa (Flavobacterium \#25 and OM43 \#25) that shared abundance peaks between 17 and 20 June and 11 and 14 August. Group II organisms (Flavobacteria \#23, 29, 44, 78, and SAR116 \#37) were relatively abundant during the early bloom stage (including post bloom), and were not detected again until after the late bloom phase. Group III, represented by 1 taxon (Sphingobacteria \#65), peaked after (but not during) the early bloom stage, and again after the late bloom stage. The next assemblage of organisms (Group IV, including Flavobacterium \#50 and Roseobacter \#18) exhibited a temporal pattern quite distinct from Groups I to III (Fig. 3). These taxa showed high intensity during the early bloom stage as well as the late bloom 
Table 2. Bacterial taxa detected by Luminex assay from 2005 Lingulodinium polyedrum bloom particles, including references where the given taxa have been identified from a marine algal bloom sample. GB acc.: GenBank accession number; Beta: Betaproteobacteria

\begin{tabular}{|c|c|c|c|c|}
\hline $\begin{array}{l}\text { Bead } \\
\text { color }\end{array}$ & GB acc. & Probe sequence & General taxon & Source \\
\hline 25 & EU733923 & TTC GAG CAC TAA AGC ATC TCT GCT A & Beta (OM43) & $\begin{array}{l}\text { Zubkov et al. (2002), Morris et al. } \\
\text { (2006), Barlaan et al. (2007) }\end{array}$ \\
\hline 18 & EU733969 & CCA TCT CTG GTA GTA GCA CAG GAT G & Roseobacter $\mathrm{RCA}^{\mathrm{a}}$ & $\begin{array}{l}\text { Too many to list; reviewed by } \\
\text { Mayali et al. (2008) }\end{array}$ \\
\hline 37 & EU734135 & TCT CCG GAA ACC AAA CTC CCC ATG T & $\begin{array}{l}\text { Rickettsiales } \\
\quad(\text { SAR116) }\end{array}$ & Fandino et al. (2001) \\
\hline 31 & EU733911 & CTA GYC TGT TTC CAA ACT ATT CGC T & $\begin{array}{l}\text { Flavobacteria/ } \\
\text { Fluviicola }\end{array}$ & $\begin{array}{l}\text { Pinhassi et al. (2004), Rooney-Varga } \\
\text { et al. (2005), Rink et al. (2007) }\end{array}$ \\
\hline 65 & EU733918 & TTC CAG AAG ACA TCA CTG TGG ATT T & $\begin{array}{c}\text { Sphingobacteria/ } \\
\text { Balneola }\end{array}$ & $\begin{array}{l}\text { Kelly \& Chistoserdov (2001), Green } \\
\text { et al. (2004) }\end{array}$ \\
\hline 78 & EU734027 & GAA GAG AAG GCC TGT TTC CAA GCC G & $\begin{array}{l}\text { Flavobacteria/ } \\
\text { Owenweeksia }^{\mathrm{a}}\end{array}$ & $\begin{array}{l}\text { Fandino et al. (2001), Brussaard et } \\
\text { al. (2005), Barlaan et al. (2007), } \\
\text { Rink et al. (2007) }\end{array}$ \\
\hline 23 & EU733921 & AGA AAA GAC CAT CTC TGA TCT ATG C & Flavobacteria/NS5 & Present study ${ }^{b}$ \\
\hline 27 & EU733954 & GAT YCA TTT CTG AAT CAT GCA ACT T & Flavobacteria/NS5 & Present study ${ }^{\mathrm{b}}$ \\
\hline 29 & EU733753 & TAT CTC TAG ACC TGT CCC ACT ACA T & Flavobacteria/NS4 ${ }^{\mathrm{a}}$ & $\begin{array}{l}\text { Fandino et al. (2001), Zubkov et al. } \\
\text { (2002), Sala et al. (2005), Rink et } \\
\text { al. (2007), Sapp et al. (2007) }\end{array}$ \\
\hline 44 & EU734009 & ATC TCT AAA GCT GTC AGA CTA CAT T & $\begin{array}{c}\text { Flavobacteria/ } \\
\text { Polaribacter }\end{array}$ & $\begin{array}{l}\text { Riemann et al. (2000), Zubkov et al. } \\
\text { (2002), Rooney-Varga et al. (2005), } \\
\text { Morris et al. (2006), Barlaan et al. } \\
\text { (2007), Rink et al. (2007) }\end{array}$ \\
\hline 45 & EU733897 & AAG GTC CAT CTC TGG TCC ATG CAA C & Flavobacteria/NS5 & $\begin{array}{l}\text { Barlaan et al. (2007), Sapp et al. } \\
(2007)\end{array}$ \\
\hline 50 & EU733757 & AAT AGC TAT CTC TAR CTA ATG CAA C & $\begin{array}{l}\text { Flavobacteria/ } \\
\text { Formosa }\end{array}$ & $\begin{array}{l}\text { Barlaan et al. (2007), Sapp et al. } \\
(2007)\end{array}$ \\
\hline
\end{tabular}

stage. Early stage intensity peaks preceded peaks from Group II organisms but resembled those of Group III organisms. Late bloom stage peaks were concurrent with the peak in algal cell abundances. Group V, represented by only 1 taxon (Flavobacterium \#31), exhibited its highest intensity peak during the middle bloom stage of relatively low algal cell abundances. It also showed a secondary peak during the late bloom stage, but earlier than Group IV organisms.

A useful technique to examine how the different bacterial taxa changed their abundances on particles over time and in relation to one another is to construct network diagrams (Fig. 4), where taxa are connected by lines corresponding to positive (solid) and negative (dashed) interactions. Many of the bacterial taxa revealed positive correlations (coefficients $>0.4$ ) among one another, with no time lags (Fig. 4a), meaning that their temporal dynamics of colonization were similar. Several taxa were also positively correlated with a time lag of $1 \mathrm{~d}$, meaning their peaks in relative abundance were on average separated by $1 \mathrm{~d}$ (e.g. Flavobacterium
\#50 peaked $1 \mathrm{~d}$ before Flavobacterium \#78; Fig. 4b). As time lags increased, the number of strong correlations decreased, but we began to detect negative correlations. For example, Flavobacterium \#45 peaked $2 \mathrm{~d}$ before decreases in Sphingobacteria \#65 (or vice versa; Fig. 4c). Such negative time-lagged correlations are more complex to interpret because they can be caused by the second taxon increasing after the first decreases, by the second taxon decreasing after the first increases, or both. Negative correlations dominated lags of $3 \mathrm{~d}$ (Fig. 4d) as well as 5 to $8 \mathrm{~d}$ (Fig. 4e). The latter analysis was the only one to detect strong correlations between bacterial taxa and Lingulodinium polyedrum abundances, all but 1 of which were negative. This means that peaks in bacterial attachment by 4 taxa (\#18, 37, $50,78)$ were followed by decreases in L. polyedrum abundances after 5 to $6 \mathrm{~d}$, and/or decreases in bacterial attachment by those taxa were followed by increases in L. polyedrum abundances after 5 to $6 \mathrm{~d}$. One taxon (\#65) showed a positive correlation 5 to $6 \mathrm{~d}$ after peaks in L. polyedrum abundances. 

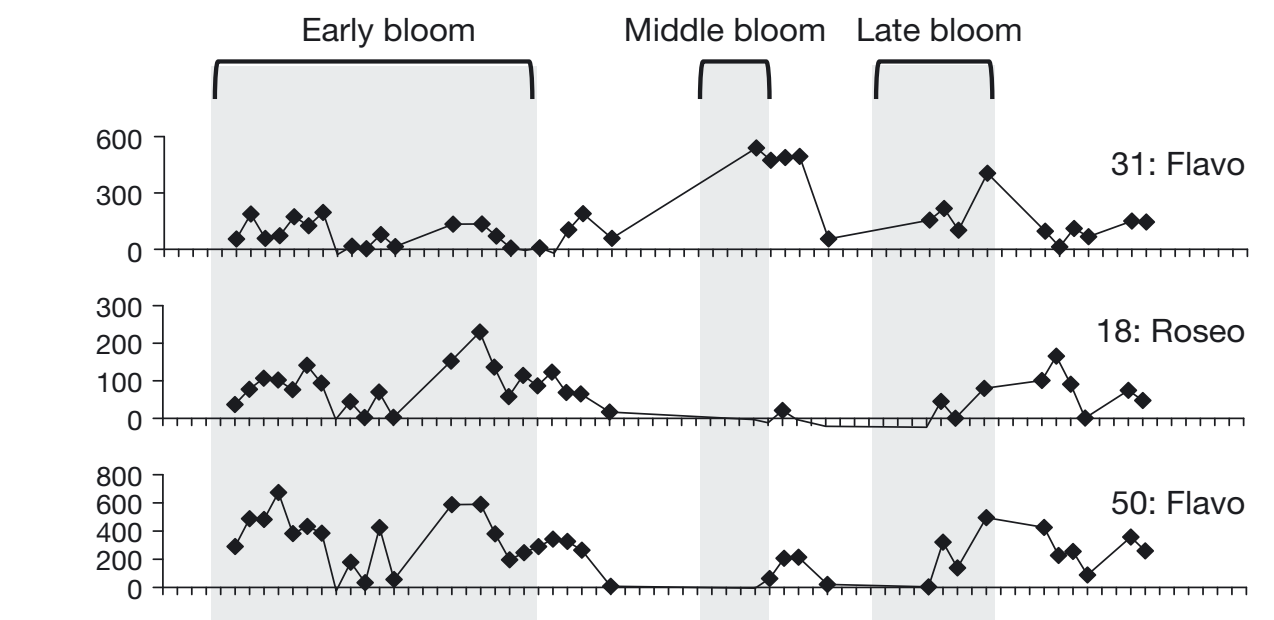

Group IV
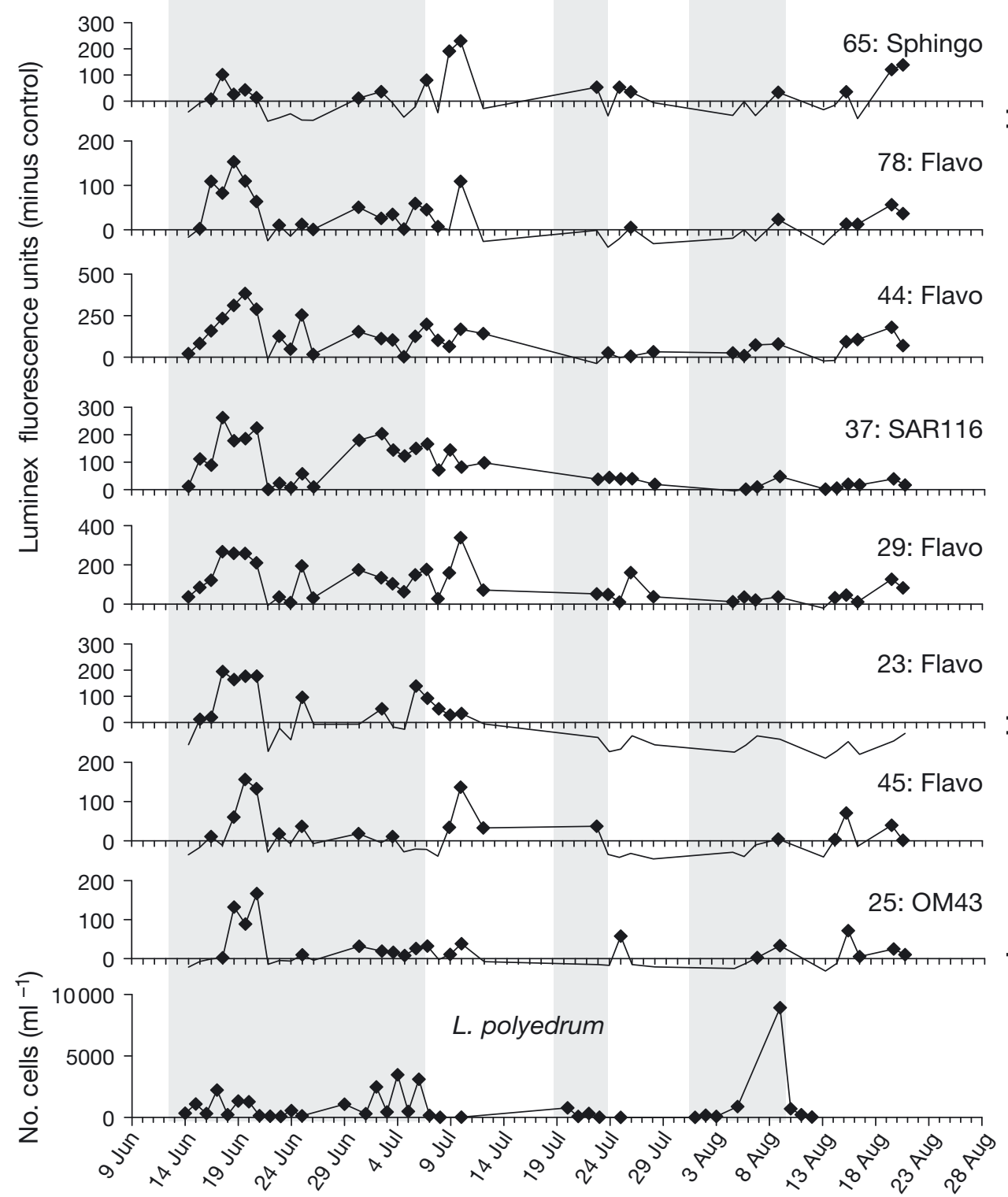

Fig. 3. Temporal dynamics of 11 bacterial taxa attached to particles over the course of a Lingulodinium polyedrum bloom measured with the Luminex assay. Three phases of high algal abundances are highlighted (shaded in gray), and the bacterial taxa are grouped according to similar dynamics measured by cluster analysis. All members of a group had a correlation coefficient ( $\mathrm{r}$ ) $>0.7$ with all other members. Names refer to the Luminex bead color and the abbreviated taxa from Table 2

(Flavo: Flavobacteria; Sphingo: Sphingobacteria; Roseo: Roseobacter) 

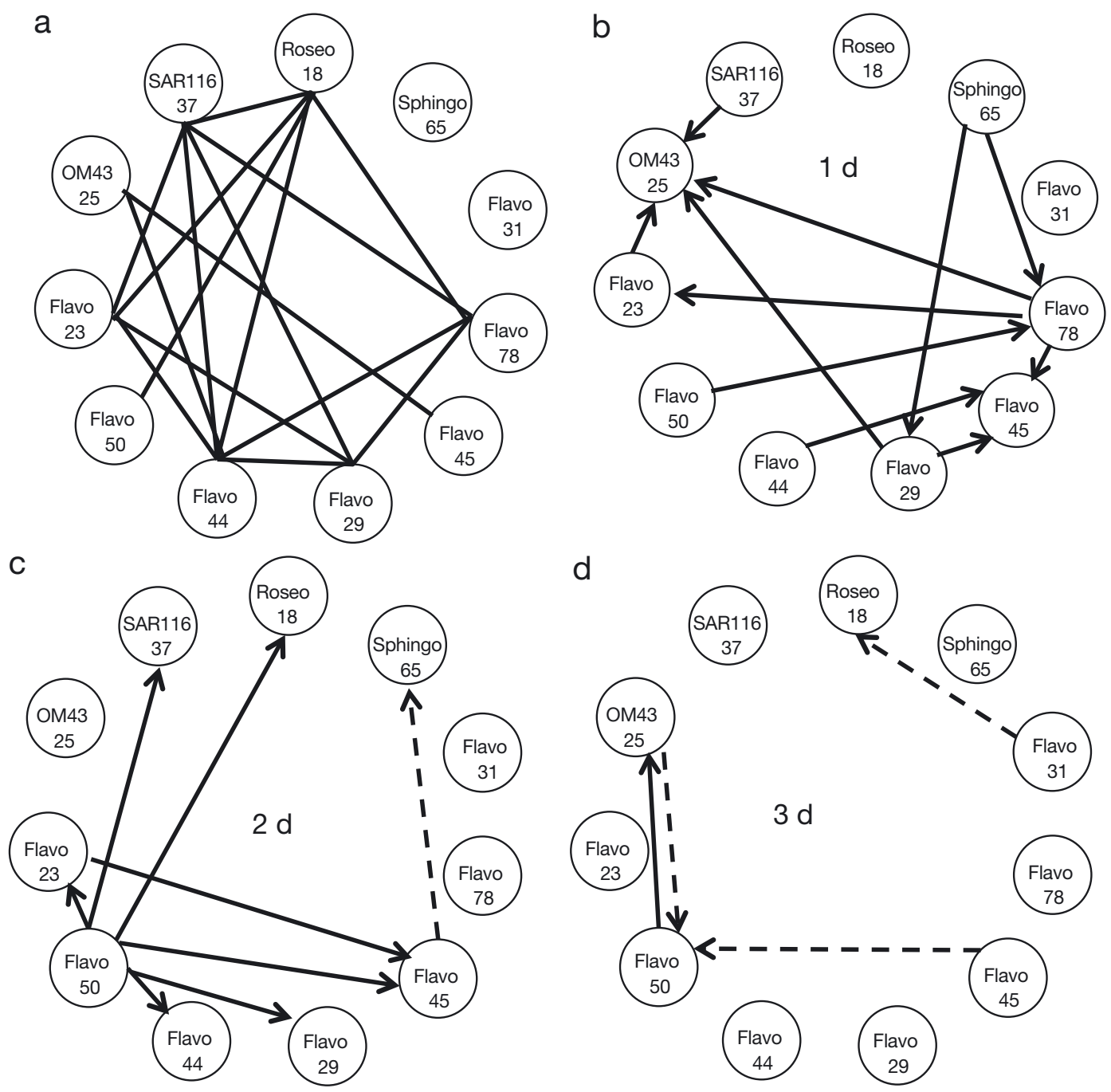

d

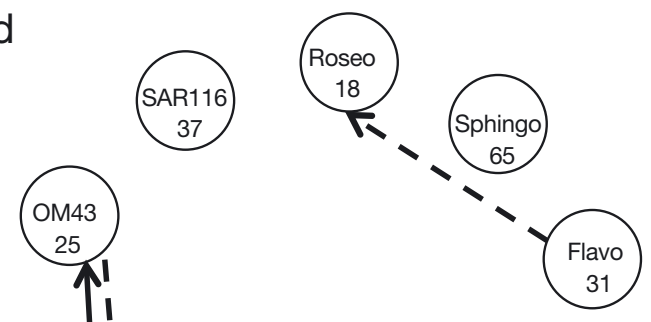

$3 d$

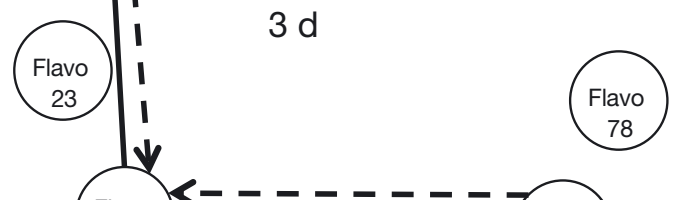

e

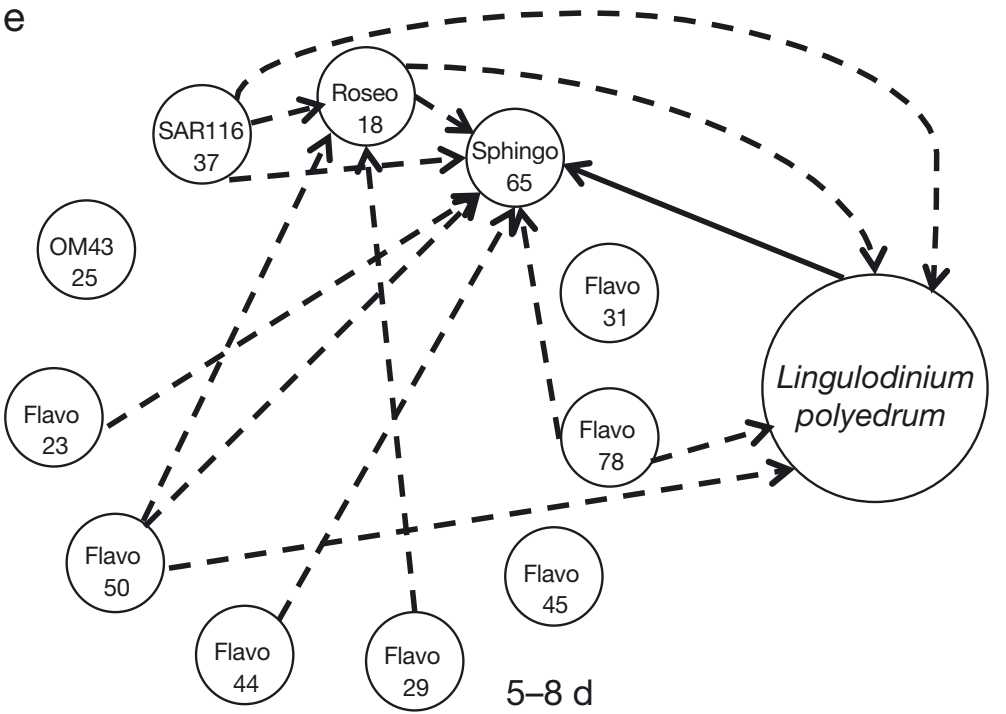

Fig. 4. Network diagrams representing positive (solid lines) and negative (dashed lines) interactions among taxa based on parametric correlations with coefficients $|r|>0.4$; (a) unlagged data, (b) lag $=1 \mathrm{~d}$, (c) lag $=2 \mathrm{~d}$, (d) $\operatorname{lag}=3 \mathrm{~d}$, (e) lag $=5$ to $8 \mathrm{~d}$. Arrows point forward in time. Names refer to the Luminex bead color and the abbreviated taxa from Table 2 (Flavo: Flavobacteria; Sphingo: Sphingobacteria; Roseo: Roseobacter) 


\section{DISCUSSION}

\section{Bacterial abundances and attachment during the bloom}

Our data showing a positive correlation between algal and free-living bacterial abundances provide evidence of bottom-up control of bacteria by the presence of the dominant algal species, presumably the major producer of organic matter during the bloom. This finding is not surprising, as phytoplankton-derived organic matter is thought to provide the majority of nutrition to bacteria (Cole 1982). What is perhaps surprising is the large range of free-living bacterial abundances, spanning over 1 order of magnitude. This demonstrates that growth and death processes were not in equilibrium during this time, a phenomenon also associated with vertically migrating dinoflagellate cells (Gasol et al. 2005). Whether this disequilibrium is ultimately caused solely by increased bacterial growth or in combination with decreased bacterial mortality is not known. One of the results, however, is that algal blooms harbor different microbial communities (reviewed by Garcés et al. 2007), presumably because increased organic matter from the algae (both dissolved and particulate) leads to the increased abundance of fast-growing copiotrophic organisms (Koch 2001).

In addition to a response of bacterial abundances to algal cell abundances, we also found that Lingulodinium polyedrum abundances peaked following peaks in bacterial abundances (with a 2 d lag), implying a positive response by the algae to the increased presence of bacteria. Assuming a causal association between the bacterial peak and subsequent algal peak, this could be explained by previous evidence that heterotrophic bacteria remineralize nutrients, leading to increased algal growth (Caron et al. 1988, Ferrier et al. 2002). In addition, there are numerous examples of direct or indirect growth-promoting effects of bacteria on phytoplankton through the release of other compounds such as vitamins (Droop 2007) and metal chelators (Amin et al. 2009). Indeed, many types of phytoplankton, dinoflagellates in particular, cannot grow without the presence of bacteria, reinforcing the idea that bacteria and phytoplankton commonly form such mutualistic associations.

With the exception of the end of the last bloom phase, we found that bacterial colonization of Lingulodinium polyedrum cells was quite low, with the majority of algal cells being free of detectable bacteria. Even during peaks in colonization frequency (near the end of a bloom event), when more than $80 \%$ of the algae were colonized, colonization intensity rarely surpassed 5 bacteria per algal cell. It should be mentioned that we sampled only the surface waters, so we cannot rule out that a different pattern of colonization was dominant at depths. Previous evidence has shown that as few as 1 or 2 attached bacterial cells can significantly affect phytoplankton physiology (Paerl \& Gallucci 1985), consistent with the numbers found here. Nevertheless, since detritus is more heavily colonized than live cells, the latter might have mechanisms to prevent bacterial colonization. Another finding was the high variability in both colonization frequency and intensity, which could change a great deal over the course of a few days (Fig. 1c,d). This is unlike previous results from Vaqué et al. (1990), who found low variability in bacterial attachment. The noted differences between this and the previous study could be due to several factors, including that we examined a natural bloom (versus a microcosm), used a different method of quantification (CARD-FISH versus DNA staining with acridine orange), and examined a different algal class (dinoflagellates versus diatoms). A particularly relevant attribute of certain thecate dinoflagellates, including $L$. polyedrum, is their ability to form temporary cysts through ecdysis (Morrill 1984), during which the cell wall, thecae, and outer cell membranes are shed. The extensive temporal variability of bacterial attachment in nature may be explained by the finding that L. polyedrum cells remove attached bacteria by ecdysis (Mayali et al. 2007). Temporary cysts of L. polyedrum have been found in nature at the end of a bloom (Marasovic 1989), and there is further evidence that dinoflagellate blooms can terminate via cyst formation (Wang et al. 2007).

The quantification of bacterial colonization frequency and intensity over the course of the Lingulodinium polyedrum bloom provided novel information about changes in algal-bacterial interactions occurring over time. Based on these data, the early and late bloom stages appeared to be quite different. The early bloom stage was characterized by relatively low bacterial colonization $\left(<1\right.$ bacterium alga $\left.^{-1}\right)$, with a small

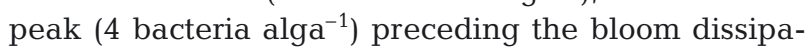
tion. The late bloom stage was characterized by higher and more variable bacterial colonization (1 to 8 bacteria $\left.\operatorname{alga}^{-1}\right)$, with a higher peak (12 bacteria alga ${ }^{-1}$ ) preceding the final bloom dissipation (Fig. 1d). The factors that might have led to such pronounced differences in bacterial colonization between the 2 bloom stages are unknown, as are the causes of both bloom dissipation events. It is conceivable that the general health status of the algal cells might have been different between the 2 bloom stages, whether due to nutrient limitation, pathogen infection, or cell ageing. Any of these factors, alone or in combination, would likely lead to the latter bloom stage comprising cells that were less healthy compared to those from the early stage. This difference 
in health, in turn, was likely to affect the ability of the algal cells from the latter stage to prevent bacterial colonization, and/or made the algal cells more leaky, leading to increased bacterial colonization through chemoattraction (Barbara \& Mitchell 2003). Future work combining bacterial attachment data and algal cell physiological status will be necessary to provide evidence for these hypotheses.

\section{Attachment dynamics of bacterial taxa}

The quantification of bacterial colonization of algal cells using CARD-FISH provided a general indication of algal-bacterial attachment dynamics over time, but changes in the identity of the attached bacteria were not identified with this method. Using the Luminex ${ }^{\circledR}$ bead array method, we found that many of the detected bacterial taxa exhibited different particle colonization dynamics over time, confirming previous studies documenting microbial community succession during algal blooms (reviewed by Garcés et al. 2007). Although the PCR-Luminex assay does not provide quantification of cell numbers, we were able to compare the data for 1 of the targeted taxa (Roseobacter RCA \#18) with a previous study that examined the number of attached cells of this same taxon (with CARD-FISH) in the same bloom samples (Mayali et al. 2008). The 2 datasets were in moderate agreement $\left(\mathrm{R}^{2}=0.30, \mathrm{p}=0.02\right)$, and peaks in Roseobacter $\mathrm{RCA}$ colonization measured with the 2 methods occurred on the same dates (30 June and 8 August). This demonstrates that the Luminex assay could be used as a proxy for taxon-specific bacterial colonization of particles. In addition, the previous study provided useful information regarding the physiological effect of attached bacteria on the algal cells, as it reported the ability of an isolate of the RCA cluster to kill algal cells after attachment. No information regarding any physiological effects of the other bacterial taxa examined here exists.

Based on the temporal patterns of relative abundances of the 11 detected bacterial taxa (Fig. 3), it is apparent that different bacteria colonized particles during different phases of the bloom. Taxa classified as Groups I and II were mostly detected in the early bloom phase when general bacterial colonization intensity was low, suggesting they played a mutualist or commensal role. The only taxon classified as Group III peaked in abundance after the first bloom stage, suggesting it preferred dead cells or detritus and likely played a saprophytic role. Group IV organisms dominated during the latter part of the early bloom phase as well as the late bloom phase. Based on the previous identification of 1 of those taxa (Roseobacter
RCA) as a dinoflagellate pathogen (Mayali et al. 2008), it is possible that the other taxon from this group (Flavobacterium \#50) plays a similar role. Future efforts to culture this organism and subsequent laboratory experiments to test its ability to kill dinoflagellates will be needed to test this hypothesis.

The network diagrams summarizing the temporal cross-correlation analyses among taxa (Fig. 4) suggest that different interactions occurred on different timescales. On shorter scales of 0 to $2 \mathrm{~d}$, it appears that positive interactions among attached bacterial taxa dominated. An interpretation of these data is that if a bacterial taxon was successfully colonizing Lingulodinium polyedrum, other bacterial taxa were likely to also colonize, either on the same day or within the following 1 or $2 \mathrm{~d}$. This scenario is reasonable provided whatever algal physiological process allowing bacterial colonization to increase was not monospecific: most bacteria that could were able to colonize the algal cells. In addition, it is possible that some bacterial taxa that colonized early facilitated the later colonization by other taxa, a phenomenon shown to occur in other surface microbial ecosystems (Jackson et al. 2001). On longer timescales of $3 \mathrm{~d}$ and above, it appears that interactions were more commonly negative, implying competition and/or chemically mediated antagonism among bacteria. The overall patterns of colonization, based on the Luminex data, suggest a complex and rapid succession with different bacterial taxa being found at different times over the course of the bloom.

The effect of dying algae on the physiology of attached bacteria is a well-established relationship, but the reverse interaction (the effect of bacteria on algae) is more subtle and can be more difficult to demonstrate, especially in nature (Cole et al. 1988). bacteria can have beneficial properties towards algae through the production of growth-promoting substances as well as inhibitory properties, both indirectly through competition for resources or directly through allelopathy (Azam \& Smith 1991, Doucette 1995). The work presented here provides evidence that bacteria should be considered as likely to play a major role in the physiology of phytoplankton, particularly through attachment to algal cells. While this idea is not novel, either in the context of algal bloom dynamics or generally, surprisingly few data from natural samples exist to support it. Future work needs to address the physiological changes in the algal cells that allow increased bacterial colonization to occur, as well as species-specific effects of attached bacteria on algal physiology. Our present inability to predict the dynamics of algal blooms, particularly those harmful to people and ecosystems, merits further research in this area. 
Acknowledgements. We are grateful to F. Malfatti for assistance in field sampling, F. Azam for advice and input to the manuscript, R. Mueller and F. Lauro for insightful discussions, and 3 anonymous reviewers for useful comments. We are indebted to J. McGowan and M. Carter for the chlorophyll data collected through the Scripps Pier Chlorophyll Program, which is funded through the Southern California Coastal Ocean Observing System. This work was funded by a NOAA/ECOHAB grant to P.J.S.F. and F. Azam and an NSF grant to R.S.B. This work was performed under the auspices of the US Department of Energy by Lawrence Livermore National Laboratory under Contract DE-AC52-07NA27344.

\section{LITERATURE CITED}

Albright LJ, McCrae SK, May BE (1986) Attached and freefloating bacterioplankton in Howe Sound, British Columbia, a coastal marine fjord-embayment. Appl Environ Microbiol 51:614-621

> Amann RI, Krumholz L, Stahl DA (1990) Fluorescent-oligonucleotide probing of whole cells for determinative phylogenetic and environmental studies in microbiology. J Bacteriol 172:762-770

Amann RI, Ludwig T, Schleifer KH (1995) Phylogenetic identification and in situ detection of individual microbial cells without cultivation. Microbiol Rev 59:143-169

Amin SA, Green DH, Hart MC, Küpper FC, Sunda WG, Carrano CJ (2009) Photolysis of iron-siderophore chelates promotes bacterial-algal mutualism. Proc Natl Acad Sci USA 106:17071-17076

Azam F, Smith DC (1991) Bacterial influence on the variability in the ocean's biogeochemical state: a mechanistic view. In: Demers S (ed) Particle analysis in oceanography. NATO ASI Series, Vol G27. Springer-Verlag, Berlin, p 213-235

Barbara GM, Mitchell JG (2003) Bacterial tracking of motile algae. FEMS Microbiol Ecol 44:79-87

Barlaan EA, Furukawa S, Takeuchi K (2007) Detection of bacteria associated with harmful algal blooms from coastal and microcosm environments using electronic microarrays. Environ Microbiol 9:690-702

Bell WH, Mitchell R (1972) Chemotactic and growth responses of marine bacteria to algal extracellular products. Biol Bull 143:265-277

Bratbak G, Egge JK, Heldal M (1993) Viral mortality of the marine alga Emiliana huxleyi (Haptophyceae) and termination of algal blooms. Appl Environ Microbiol 66: 4916-4920

Brussaard CPD, Marie X, van Bleijswijk JD, Veldhuis MJ (2005) A mesocosm study of Phaeocystis globosa (Prymnesiophyceae) population dynamics. II. Significance for the microbial food web. Harmful Algae 4: 875-893

> Caron DA, Davis PG, Madin LP, Sieburth JM (1982) Heterotrophic bacteria and bacterivorous protozoa in oceanic macroaggregates. Science 218:795-797

Caron DA, Goldman JC, Dennett MR (1988) Experimental demonstration of the role of bacteria and bacterivorous protozoa in plankton nutrient cycles. Hydrobiologia 159: $27-40$

> Coats DW, Adams EJ, Gallegos CL, Hedrick S (1996) Parasitism of photosynthetic dinoflagellates in a shallow subestuary of Chesapeake Bay, USA. Aquat Microb Ecol 11: $1-9$

> Cole JJ (1982) Interactions between bacteria and algae in aquatic ecosystems. Annu Rev Ecol Syst 13:291-314
Cole JJ, Findlay S, Pace ML (1988) Bacterial production in fresh and saltwater ecosystems: a cross-system overview. Mar Ecol Prog Ser 43:1-10

> Doucette GJ (1995) Interactions between bacteria and harmful algae: a review. Nat Toxins 3:65-74

> Droop MR (2007) Vitamins, phytoplankton and bacteria: symbiosis or scavenging? J Plankton Res 29:107-113

Droop MR, Elson KGR (1966) Are pelagic diatoms free from bacteria? Nature 211:1096-1097

Fandino LB, Riemann L, Steward GF, Long RA, Azam F (2001) Variations in bacterial community structure during a dinoflagellate bloom analyzed by DGGE and 16S rDNA sequencing. Aquat Microb Ecol 23:119-130

> Ferrier M, Martin J, Rooney-Varga J (2002) Stimulation of Alexandrium fundyense growth by bacterial assemblages from the Bay of Fundy. J Appl Microbiol 92:706-716

Garcés E, Vila M, Reñé A, Alonso-Sáez L and others (2007) Natural bacterioplankton assemblage composition during blooms of Alexandrium spp. (Dinophyceae) in NW Mediterranean coastal waters. Aquat Microb Ecol 46: $55-70$

> Gasol JM, Garcés E, Vila M (2005) Strong small-scale temporal bacterial changes associated with the migrations of bloom-forming dinoflagellates. Harmful Algae 4:771-781

Green DH, Llewellyn LE, Negri AP, Blackburn SI, Bolch CJS (2004) Phylogenetic and functional diversity of the cultivable bacterial community associated with the paralytic shellfish poisoning dinoflagellate Gymnodinium catenatum. FEMS Microbiol Ecol 47:345-357

- Hasegawa Y, Martin JL, Giewat MW, Rooney-Varga JN (2007) Microbial community diversity in the phycosphere of natural populations of the toxic alga, Alexandrium fundyense. Environ Microbiol 9:3108-3121

Ideker T, Thorsson V, Ranish JA, Christmas R and others (2001) Integrated genomic and proteomic analyses of a systematically perturbed metabolic network. Science 292: 929-934

> Jackson CR, Churchill PF, Roden EE (2001) Successional changes in bacterial assemblage structure during epilithic biofilm development. Ecology 82:555-566

Kelly KM, Chistoserdov AY (2001) Phylogenetic analysis of the succession of bacterial communities in the Great South Bay (Long Island). FEMS Microbiol Ecol 35:85-95

- Koch AL (2001) Oligotrophs versus copiotrophs. Bioessays 23: 657-661

Kodama M, Doucette G, Green D (2006) Relationships between bacteria and harmful algae. In: Granéli E, Turner JT (eds) Ecology of harmful algae, Vol 189. Springer, Berlin, p 243-255

Kogure K, Simidu U, Taga N (1981) Bacterial attachment to phytoplankton in sea water. J Exp Mar Biol Ecol 56: 197-204

> Lam P, Cowen JP (2004) Processing deep-sea particle-rich water samples for fluorescent in situ hybridization: consideration of storage effects, preservation, and sonication. Appl Environ Microbiol 70:25-33

Lebaron P, Parthuisot N, Catala P (1998) Comparison of blue nucleic acid dyes for flow cytometric enumeration of bacteria in aquatic systems. Appl Environ Microbiol 64: 1725-1730

Marasovic I (1989) Encystment and excystment of Gonyaulax polyedra during a red tide. Estuar Coast Shelf Sci 28: $35-41$

> Mayali X, Franks PJS, Azam F (2007) Bacterial induction of temporary cyst formation by the dinoflagellate Lingulodinium polyedrum. Aquat Microb Ecol 50:51-62 
Mayali X, Franks PJS, Azam F (2008) Cultivation and ecosystem role of marine RCA cluster bacterium. Appl Environ Microbiol 74:2595-2603

Mayali X, Palenik B, Burton RS (2010) Dynamics of marine bacterial and phytoplankton populations using multiplex liquid bead array technology. Environ Microbiol 12: 975-989

Morrill LC (1984) Ecdysis and the location of the plasma membrane in the dinoflagellate Heterocapsa niei. Protoplasma 119:8-20

Morris RM, Longnecker K, Giovannoni SJ (2006) Pirellula and OM43 are among the dominant lineages identified in an Oregon coast diatom bloom. Environ Microbiol 8: 1361-1370

Paerl HW (1975) Microbial attachment to particles in marine and freshwater ecosystems. Microb Ecol 2:73-83

Paerl HW, Gallucci KK (1985) Role of chemotaxis in establishing a specific nitrogen-fixing cyanobacterial-bacterial association. Science 227:647-649

Pernthaler A, Pernthaler J, Amann R (2002) Fluorescence in situ hybridization and catalyzed reporter deposition for the identification of marine bacteria. Appl Environ Microbiol 68:3094-3101

Pinhassi J, Sala MM, Havskum H, Peters F, Guadayol O, Malits A, Marrase C (2004) Changes in bacterioplankton composition under different phytoplankton regimens. Appl Environ Microbiol 70:6753-6766

Porter KG, Feig YS (1980) The use of DAPI for identifying and counting aquatic microflora. Limnol Oceanogr 25: 943-948

Riemann L, Steward GF, Azam F (2000) Dynamics of bacterial community composition and activity during a mesocosm diatom bloom. Appl Environ Microbiol 66:578-587

Rink B, Seeberger S, Martens T, Duerselen CD, Simon M, Brinkhoff T (2007) Effects of a phytoplankton bloom in a

Editorial responsibility: Gunnar Bratbak,

Bergen, Norway coastal ecosystem on the composition of bacterial communities. Aquat Microb Ecol 48:47-60

Rooney-Varga JN, Giewat MW, Savin MC, Sood S, LeGresley M, Martin JL (2005) Links between phytoplankton and bacterial community dynamics in a coastal marine environment. Microb Ecol 49:163-175

Sala MM, Balague V, Pedros-Alio C, Massana R and others (2005) Phylogenetic and functional diversity of bacterioplankton during Alexandrium spp. blooms. FEMS Microbiol Ecol 54:257-267

Sapp M, Wichels A, Wiltshire KH, Gerdts G (2007) Bacterial community dynamics during the winter-spring transition in the North Sea. FEMS Microbiol Ecol 59:622-637

> Smith DC, Simon M, Alldredge AL, Azam F (1992) Intense hydrolytic enzyme activity on marine aggregates and implications for rapid particle dissolution. Nature 359:139-142

Spiro A, Lowe M, Brown D (2000) A bead-based method for multiplexed identification and quantitation of DNA sequences using flow cytometry. Appl Environ Microbiol 66:4258-4265

Vaqué D, Duarte CM, Marrasé C (1989) Phytoplankton colonization by bacteria: encounter probability as a limiting factor. Mar Ecol Prog Ser 54:137-140

Vaqué D, Duarte CM, Marrasé C (1990) Influence of algal population dynamics on phytoplankton colonization by bacteria: evidence from two diatom species. Mar Ecol Prog Ser 65:201-203

Wang ZH, Qi YZ, Yang YF (2007) Cyst formation: an important mechanism for the termination of Scrippsiella trochoidea (Dinophyceae) bloom. J Plankton Res 29:209-218

Zubkov MV, Fuchs BM, Archer SD, Kiene RP, Amann R, Burkill PH (2002) Rapid turnover of dissolved DMS and DMSP by defined bacterioplankton communities in the stratified euphotic zone of the North Sea. Deep-Sea Res Part II 49:3017-3038

Submitted: October 11, 2010; Accepted: December 12, 2010 Proofs received from author(s): March 21, 2011 